\title{
Selected Aspects of Molecular Diagnostics of Constitutional Alterations in BRCAI and BRCA2 Genes Associated with Increased Risk of Breast Cancer in the Polish Population
}

\author{
Bohdan Górski \\ Department of Genetics and Pathology, International Hereditary Cancer Centre, Pomeranian Medical University, Szzzecin, Poland
}

Key words: breast cancer, ovarian cancer, inherited predisposition, BRCA1, BRCA2

Corresponding author: Bohdan Górski, Department of Genetics and Pathology, International Hereditary Cancer Centre, Pomeranian Medical University, Połabska 4,70-115 Szczecin, Poland, e-mail: gorskib@sci.pam.szczecin.pl

Submitted: 24 July 2006

Accepted: 2 August 2006

\begin{abstract}
Objectives: This study was undertaken to determine: 1) Type and prevalence of founder mutations BRCA1 and BRCA2 genes in Polish families with strong aggregation of breast and/or ovarian cancer. 2) Risk of breast and/or ovarian cancer depending on type of BRCA1 gene mutation. 3) Prevalence of BRCA1 mutation and of other alleles presumably linked with predisposition to breast cancer in unselected Polish patients with breast cancer. 4) Risk of breast cancer in patients with 5972C/T polymorphism that alters the BRCA2 protein structure. Summary of the results: 1. Among 66 families from several regions in Poland with a strong aggregation of breast/ovarian cancer, founder mutation of the BRCA1 gene were disclosed in 34 families and of the BRCA2 gene in on family. Altogether, seven different mutations were disclosed. Five mutations were found in at least two families in this group. The most frequent mutation was 5382insC (18 families), followed by C61G (7 families) and 4153 delA (4 families). 2. Among 200 families representative for Poland with strong aggregation of breast/ovarian cancer, mutation of the BRCA1 gene were found in 122 families (61\%) and of the BRCA2 gene in seven families (3,5\%). 119 out of 122 mutations of the BRCA1 gene (97,5\%) were repeatable. Three recurrent mutations of the BRCA1 gene (5382insC, C61G, 4153delA) characteristic for the Polish population were disclosed in 111 families representing $86 \%$ of all pathogenic sequences of this gene. 3. The risk of ovarian cancer in carriers of the three most frequent recurrent mutation of the BRCA 1 gene in Poland is similar (OR 43.6 for $5382 \mathrm{ins} C$ and 50 for $4153 \mathrm{del}$ ). The risk of breast cancer is significantly different for $4153 \mathrm{deIA}(\mathrm{OR} 1)$ and for other mutations (OR 10.9). 4. Among 2012 unselected breast cancers diagnosed in hospitals of nine Polish cities, mutations of the BRCA1 gene (5382insC, C61 G, 4153delA) were disclosed in $2.9 \%$ patients. CHEK2 alternation (1 100delC, IVS2 + 1G>A, 1157T) was discovered in $8.1 \%$ and NBS1 mutation (657del5) in $0.8 \%$ of the patients. The changes were more frequent in the study than the control group. However, the risk of breast cancer was significantly higher for only three of them. Two changes, namely 5382insC and C61G of the BRCA1 gene revealed a high penetrance (OR 6.2 and 15.0, respectively), while I157T of the CHEK2 gene was associated with a low risk of breast cancer (OR 1.4). Mutations of the BRCA1, CHEK2 and NSB1 genes were significantly more frequent in patients with breast cancer diagnosed prior to 50 years of age. The mean age at diagnosis was 47.2 years for carriers of the BRCA1 mutation, 50.7 years for NBS1 and 54.2 for CHEK2. The mean age at diagnosis in the group of patients without any if the mutations described above was 56.1 years. When breast cancer patients with the diagnosis before and after 50 years of age were compared, the greatest difference in the frequency of mutation was revealed for the BRCA1 gene (5.5\% vs $1.5 \%)$.
\end{abstract}


BRCA1 mutations were significantly more frequent I familial aggregates of the tumor $(10.8 \%)$, but were also present in sporadic cases (1.8\%). For the CHEK2 and NBS1 genes, there was no correlation between frequency and family history of cancer in probands. 5. A higher frequency of heterozygous carriers of $5972 \mathrm{C} / \mathrm{T}$ polymorphism of the BRCA2 gene was demonstrated for breast cancer prior to 50 years of age (OR 1.4). the risk of breast cancer prior to 50 years of age was particularly high in 5972T/T homozygote (OR 4.7). This polymorphism was associated with breast cancer notable for intraductal growth.

Conclusions: 1. Efficient molecular diagnostics of genetic predisposition to breast/ovarian cancer in Poland could be based on relatively simple tests disclosing some of the most frequent recurrent mutations of the BRCAT gene. 2. The risk of breast cancer seems to be only slightly higher in carriers of some BRCAl gene mutations. This finding should be taken into account during work on prevention schemes for carriers of the BRCA1 mutations. 3. 5382ins $C$ and $C 61 G$ mutations of the BRCA1 gene are linked with high risk of breast cancer. Changes in the CHEK2 and NBS1 genes appear to be linked with a higher risk of breast cancers, particularly at young age. However, penetrance in this case is low. All patients with breast cancer should be tested for BRCAl gene mutations because the percentage of mutations is also high in patients older than 50 years of age or without familiar aggregation of breast/ovarian cancer. 4. Polymorphic changes in the BRCA2 gene sequence previously regarded as non-pathogenic may nevertheless predispose, homozygotes in particular, to breast cancer. Apparently, the recessive character of these changes is responsible for the negative family history in most cases. The use of DNA tests is the only way to disclose increased risk of breast cancer in carriers of the 5972T/T mutation.

\section{Introduction}

BRCA1 and BRCA2 gene mutations have been described as the most common cause of high hereditary predisposition to breast and ovarian cancer. A major objective is to define the type and frequency of these mutations to obtain the most common changes.

A genetics test, effective both medically and economically, can be developed provided an unlimited number of mutation analyses among persons matching appropriate clinical and pedigree data are performed.

A large register of mutation carriers can be organized only if unlimited access to DNA testing can be achieved. In such a way actual data on genotype-phenotype correlations can be obtained, which would allow improvement in routine medical practice, such as risk assessment depending on BRCAl gene mutation type.

Among genes associated with increased genetic predisposition to tumours the frequency of alterations recognized until recently as polymorphism leading to protein change is increased. Probably a proportion of such alterations can be pathogenic and can predispose to breast cancer similarly as with mutations.

\section{Study objectives}

This study was undertaken to determine:

1. Type and prevalence of founder mutation BRCA and BRCA2 genes in Polish families with strong aggregation of breast and/or ovarian cancer;
2. Risk of breast and/or ovarian cancer depending on type of BRCA 7 gene mutation;

3. Prevalence of BRCA 1 mutation and of other alleles presumably linked to predisposition to breast cancer in unselected Polish patients with breast cancer.

4. Increased risk of breast cancer in patients with $5972 \mathrm{C} / \mathrm{T}$ polymorphism that alters the BRCA2 protein structure.

\section{Materials, methods and results}

Type and prevalence of BRCA1 and BRCA2 founder mutations in Polish families with strong aggregation of breast and/or ovarian cancer

Evidence for a strong domination effect by the BRCA1 gene based on a limited number of recurrent mutations in the Polish population

(Based on publication no. 1: Górski B et al. Founder mutations in the BRCAl gene in Polish families with breast-ovarian cancer. Am J Hum Genet 2000; 66: 1963-1968)

Many different $B R C A 1$ and $B R C A 2$ mutations have been described as a cause of high hereditary predisposition to breast and ovarian cancer. I and BRCA2 are both large genes, and complete analysis of the coding regions is expensive and time-consuming. Founder mutations of BRCA1 and BRCA2 gene in other populations have also been described.

The presence of recurrent mutations in BRCAl and BRCA2 suggests the presence of founder effects; this was first confirmed in the Ashkenazi Jewish population. 
In the studies concerning identyfing aforementioned genes mutations it was not able to separate the diversity of alterations which would allow creating diagnostic tests consisting in examining limited numbers of DNA changes. It was a consequence of the facts that the groups of cases examined in early papers were not large enough and the majority included sporadic or familiar tumours, but without strong aggregation of breast and ovarian cancers. The possibility of occurence of BRCA7 and BRCA2 gene mutations showing founder effects in the Polish population was an open question.

The present study suggests that in Poland families with BRCA1 and BRCA2 have a genetic predisposition to breast and ovarian cancers.

\section{Materials and methods}

The study group consisted of 66 Polish families with high hereditary predisposition to breast and ovarian cancer who were drawn from the Oncology Centres in Szczecin (58 families), Wrocław (7 families) and Łódź (3 families), Poland.

In each family, at least three related female relatives were affected by breast or ovarian cancer, and at least one cancer was diagnosed at patient age $<50$ years. A total of 27 families had both breast and ovarian cancers, whereas 4 families had ovarian cancers only and 35 families had breast cancer only. Blood samples for genetic analyses of genes BRCA1 and BRCA2 were taken from the youngest of these women. Genomic DNA was prepared from peripheral blood leukocytes.

The entire coding region of BRCA1 and BRCA2 was screened for the presence of germline mutations in BRCA 1 and BRCA2, by use of SSCP followed by direct sequencing of variants. Samples were sequenced with the use of fluorescently labelled dideoxy-chain terminators from the ABI Prism Kit (PE Biosystems), in a model 373 automated DNA Sequencer (PE Biosystems).

\section{Results}

Mutations were found in 35 of families studied. All but one of the mutations was detected within the BRCA1 gene. The single family with a BRCA2 mutation presented with the breast-ovarian cancer syndrome.

The mutation-detection rate was dependent on the number of ovarian cancers: BRCA1 abnormalities were identified in 100\% of four families with ovarian cancers only, in $67 \%$ of families with breast and ovarian cancers, and in $34 \%$ of families with breast cancers only.

Seven distinct mutations were identified, and five of these occurred in at least two different families. Three BRCA1 mutations - 5382insC, C61G, and 4153delA
- accounted for $82 \%$ of all identified mutations. The most frequent mutation in the present series was BRCA1 5382insC, which occurred in 18 families with mutations. The second most commonly observed mutation in the present study was BRCA1 C61G, which occurred in 7 families with mutation. The third recurrent mutation found in Polish patients, BRCA1 4153delA, was detected in 4 families.

Detailed description of BRCA1 and BRCA2 gene mutation in a representative group of Polish families with strong aggregation of breast or breast and ovarian cancer

(Based on publication no. 2: Górski B et al. A high proportion of founder BRCA1 mutations in Polish breast cancer families. Int J Cancer 2004; 1 10: 638-686)

Three mutations in BRCA1 (5382insC, C61 G and $4153 \mathrm{de}(\mathrm{A})$ are common in Poland and account for the majority of mutations identified to date in Polish breast and breast-ovarian cancer families. To establish the relative contributions of founder and nonfounder BRCA mutations, we established the entire spectrum of BRCA 1 and BRCA2 mutations in a large set of breast-ovarian cancer families with origins in all regions of Poland. It is not known, however, to what extent these three founder mutations account for all of the BRCA mutations distributed throughout the country.

Our goal was to describe the frequency of BRCA1 and BRCA2 constitutional mutations in a series of 200 breast cancer and breast-ovarian cancer families representing all regions of Poland and to determine the relative contributions of founder and nonfounder mutations. Our study was conducted to advise on national genetic screening policies for the Polish population.

\section{Materials and methods}

A total of 200 families were selected for study. One hundred families contained three or more cases of breast cancer and no case of ovarian cancer, and 100 families contained at least one case of breast cancer and one case of ovarian cancer (minimum 3 cases total). These families were selected for study from among those seeking genetic counselling at one of 18 affiliated cancer genetics centres situated throughout Poland. Information about cancers in relatives was obtained from patient interview. Families were recruited from the 18 centres so that the number of families contributed by each centre corresponded to the size of the reference population. Genomic DNA was prepared from peripheral blood leukocytes using a nonenzymatic, rapid method. 
Table 1. Mutation of BRCA1 and BRCA2 genes in 66 families with evidence of strong genetic predisposition to breast and/or ovarian cancer

\begin{tabular}{|c|c|c|c|c|c|c|}
\hline \multirow[t]{2}{*}{ Family No. } & \multirow[t]{2}{*}{ Exon } & \multirow[t]{2}{*}{ Codon } & \multirow[t]{2}{*}{ Mutation } & \multicolumn{3}{|c|}{ Family history of cancer } \\
\hline & & & & breast cancer & ovarian cancer & other \\
\hline \multicolumn{7}{|c|}{ BRCAl } \\
\hline 4506 & 20 & 1756 & 5382insC & 3 & & \\
\hline 3311 & 20 & 1756 & 5382insC & 3 & & \\
\hline 4412 & 20 & 1756 & 5382insC & 3 & & \\
\hline 1633 & 20 & 1756 & 5382ins C & 3 & & colon \\
\hline 4508 & 20 & 1756 & 5382insC & 2 & 1 & \\
\hline 3319 & 20 & 1756 & 5382insC & 2 & 1 & \\
\hline 3088 & 20 & 1756 & 5382ins C & 2 & 2 & lymphoma \\
\hline 3572 & 20 & 1756 & 5382ins C & 3 & & \\
\hline 4545 & 20 & 1756 & 5382ins C & 3 & & colon, stomach \\
\hline 1738 & 20 & 1756 & 5382ins C & 4 & 3 & colon \\
\hline 1582 & 20 & 1756 & 5382insC & 3 & & prostate \\
\hline 4478 & 20 & 1756 & 5382ins C & 3 & & \\
\hline 1387 & 20 & 1756 & 5382ins C & 4 & 1 & colon \\
\hline 2863 & 20 & 1756 & 5382insC & 4 & 2 & \\
\hline 4968 & 20 & 1756 & 5382insC & & 4 & stomach, CSU, unknown \\
\hline 5715 & 20 & 1756 & 5382ins C & 3 & & \\
\hline 5726 & 20 & 1756 & 5382insC & 1 & 2 & \\
\hline 4030 & 20 & 1756 & 5382ins C & 3 & & lung, leukaemia \\
\hline 1581 & 5 & 61 & C61G & 2 & 2 & CSU, unknown \\
\hline 1888 & 5 & 61 & C61G & 4 & & \\
\hline 4859 & 5 & 61 & C61G & 3 & & \\
\hline 3004 & 5 & 61 & C61G & 7 & & \\
\hline 4858 & 5 & 61 & C61G & 4 & & \\
\hline 5850 & 5 & 61 & C61G & 2 & 1 & \\
\hline 4854 & 5 & 61 & C61G & 3 & & skin \\
\hline 2984 & 11 & 1345 & 4153delA & 2 & 1 & \\
\hline 4278 & 11 & 1345 & 4153delA & & 4 & \\
\hline 3080 & 11 & 1345 & 4153delA & 2 & 2 & colon \\
\hline 5939 & 11 & 1345 & 4153delA & & 4 & leukaemia \\
\hline 1601 & 2 & 23 & 185delAG & 3 & & \\
\hline 703 & 2 & 23 & 185 delAG & 3 & & lung \\
\hline 3910 & 11 & 1234 & 3819 del5 & 3 & & \\
\hline 5763 & 11 & 1234 & 3819del5 & 2 & 2 & colon, lung \\
\hline 5746 & 5 & 64 & C64G & 4 & 1 & lung, colon, leukaemia \\
\hline \multicolumn{7}{|c|}{$\mathrm{BRCA2}$} \\
\hline 3874 & 27 & 3401 & T3401M & 2 & 1 & colon \\
\hline
\end{tabular}

CSU - cancer site unknown 
Table 2. Frequency of BRCA 7 mutations in 200 families with evidence of strong genetic predisposition to breast and ovarian cancer

\begin{tabular}{|c|c|c|c|c|}
\hline Mutation & Exon & $\begin{array}{c}\text { Families } \\
\text { with organ-specific } \\
\text { breast cancer }\end{array}$ & $\begin{array}{c}\text { Families } \\
\text { with breast } \\
\text { and ovarian } \\
\text { cancer }\end{array}$ & Total \\
\hline 5382insC & 20 & 36 & 32 & $68(34.0 \%)$ \\
\hline C61G & 5 & 16 & 15 & 31 (15.5\%) \\
\hline 4152delA & 11 & 3 & 9 & $12(6.0 \%)$ \\
\hline $5370 \mathrm{C} / \mathrm{T}$ & 20 & 3 & - & $3(1.5 \%)$ \\
\hline 3819del5 & 11 & 1 & 2 & $3(1.5 \%)$ \\
\hline 794delT & 11 & - & 2 & $2(1.0 \%)$ \\
\hline 185delAG & 2 & - & 1 & $1(0.5 \%)$ \\
\hline 2985 del5 & 11 & - & 1 & $1(0.5 \%)$ \\
\hline 5149del4 & 17 & 1 & - & $1(0.5 \%)$ \\
\hline total & & $60(60 \%)$ & $62(62 \%)$ & 122 (61.0\%) \\
\hline
\end{tabular}

For each family, a single affected woman was selected for study. In general, this was the youngest affected woman in the family. When more than one blood sample was available for testing, the sample from the youngest woman was chosen.

The entire coding sequence of the BRCAl and BRCA2 genes, including splice sites, was amplified by $P C R$, with minor modifications. Exon 11 of the BRCA1 gene and exons 10 and 11 of BRCA2 were amplified, each in one fragment, using primers located in the adjacent introns and the Expand Long Template PCR Kit. Purified PCR products were sequenced directly using the DNA Sequencing Kit with BigDye Terminator, version 3.0 (Applied Biosystems). Products of sequencing reactions were separated and analyzed on a 377 DNA Sequencer (Applied Biosystems).

\section{Results}

A BRCA1 mutation was detected in 122 families (61\%) and a BRCA2 mutation in 7 (3.5\%) families Tables 2 and 3. Of the 122 BRCA1 mutations, 119 $(97.5 \%)$ were found in more than one family. The 3 most common mutations accounted for 111 of the 122 (91.0\%) BRCA1 mutations detected and for $86.0 \%$ of all detected mutations. There was no clear difference in the distribution of individual mutations between families with and without ovarian cancer, with the possible exception of the 4153delA mutation. Of the 12 families with this specific mutation, 9 had one or more cases of
Table 3. Frequency of mutations and of unclassified variants of the BRCA2 gene in 200 families with evidence of strong genetic predisposition to breast or breast and ovarian cancer

\begin{tabular}{|c|c|c|c|c|}
\hline Mutation & Exon & $\begin{array}{c}\text { Families } \\
\text { with organ-specific } \\
\text { breast cancer }\end{array}$ & $\begin{array}{c}\text { Families } \\
\text { with breast } \\
\text { and ovarian } \\
\text { cancer }\end{array}$ & Total \\
\hline 488delCT & 3 & - & 1 & 1 \\
\hline 3427delA & 11 & 1 & - & 1 \\
\hline 5467ins $T$ & 11 & 1 & - & 1 \\
\hline $7235 \mathrm{G} / \mathrm{A}$ & 13 & 1 & - & 1 \\
\hline 8138del5 & 17 & 1 & - & 1 \\
\hline 9068delA & 22 & 1 & - & 1 \\
\hline 9630delC & 25 & 1 & - & 1 \\
\hline Total & & $6(6 \%)$ & $1(1 \%) 7$ & (3.5\%) \\
\hline $\begin{array}{l}\text { Sequence } \\
\text { variants }\end{array}$ & Exon & $\begin{array}{c}\text { Families } \\
\text { with organ-specific } \\
\text { breast cancer }\end{array}$ & $\begin{array}{c}\text { Families } \\
\text { with breast } \\
\text { and ovarian } \\
\text { cancer }\end{array}$ & Total \\
\hline $1093 \mathrm{~A} / \mathrm{C}$ & 10 & 1 & 2 & 3 \\
\hline $2578 \mathrm{~A} / \mathrm{G}$ & 11 & - & 1 & 1 \\
\hline 4486G/T & 11 & 1 & 2 & 3 \\
\hline $5972 \mathrm{C} / \mathrm{T}$ & 11 & 2 & 1 & 3 \\
\hline $9079 \mathrm{G} / \mathrm{A}$ & 22 & 1 & - & 1 \\
\hline
\end{tabular}

ovarian cancer. There were no clear differences in the prevalence of mutations by geographic region. In all, BRCA2 mutations were unique (i.e. none seen in more than one family). Six of the 7 BRCA2 mutations were found in families with site-specific breast cancer, and one was found in a breast-ovarian cancer family.

During sequencing several polymorphic changes within BRCA1 and BRCA2 were identified. Also, BRCA1 gene polymorphisms localized within promoter exons 11,13 and 16 and introns 9 and 18 showed complete linkage. Because there was no exception to the above observation among heterozygote carriers of the above polymorphism it is possible to exclude large deletions of the BRCA1 gene covering polymorphic regions of these genes in more than one third (38\%) of examined families without mutations detectable by sequencing (Table 4). We found 5 DNA alterations which were not clarified as neutral polymorphism or changes associated with predisposition to cancer of the breast or ovary (Table 3). 
Table 4. BRCAl gene polymorphism in probands without BRCAl and BRCA2 gene mutation as shown by sequencing

\begin{tabular}{|c|c|c|c|}
\hline Nucleotide & Amino acid swap & Exon/intron & Frequency \\
\hline IVS8-58delT & NC & 7 & $\begin{array}{c}\text { Wt/Wt } 33 \\
\text { WT/delT } 30 \\
\text { delT/delT } 8\end{array}$ \\
\hline $1186 \mathrm{~A} / \mathrm{G}$ & Gln356Arg & 11 & 6 \\
\hline 2430T/C & Leu771Leu & 11 & $\begin{array}{l}T / T 33 \\
T / C 30 \\
C / C 8\end{array}$ \\
\hline $2731 \mathrm{C} / \mathrm{T}$ & Pro871Leu & 11 & $\begin{array}{c}C / C 33 \\
C / T 30 \\
T / T 8\end{array}$ \\
\hline $3367 A / G$ & Lys 1183 Arg & 11 & $\begin{array}{l}\text { A/A } 33 \\
\text { A/G } 30 \\
\text { G/G } 8\end{array}$ \\
\hline $4427 \mathrm{~T} / \mathrm{C}$ & Ser1436Ser & 13 & $\begin{array}{l}\text { T/T } 33 \\
T / C 30 \\
\text { C/C } 8\end{array}$ \\
\hline $4956 \mathrm{~A} / \mathrm{G}$ & Ser1613Gly & 16 & $\begin{array}{l}\text { A/A } 33 \\
\text { A/G } 30 \\
\text { G/G } 8\end{array}$ \\
\hline IVS18+66G/A & $\mathrm{NC}$ & 18 & $\begin{array}{c}\text { G/G } 33 \\
\text { G/A } 30 \\
\text { A/A } 8\end{array}$ \\
\hline IVS20+60ins 12 & $\mathrm{NC}$ & 20 & 2 \\
\hline
\end{tabular}

$\mathrm{NC}$ - non-coding sequence; $\mathrm{W}_{\dagger}$ - wild-type sequence

\section{Assessment of the risk of breast/ovarian cancer depending on type of BRCAl gene mutation - evidence for low breast cancer risk in carriers of the 4153delA mutation}

(Based on publication No. 3: Górski B et al. A protein truncating $B R C A 1$ allele with a low penetrance of breast cancer. J Med Genet 2004; 41: 130-131)

Recurrent BRCA1 gene mutation can be detected in families with hereditary site specific predisposition to breast cancer as well as in families with breast and ovarian cancer.

There is some evidence that families with mutations in the central part of BRCA1 have a higher than expected ratio of ovarian to breast cancers, due to a lower than average risk of breast cancer. The absolute and relative risks of breast and ovarian cancers associated with different mutations have been difficult to quantify, in part because of the large number of different mutations in the gene, the rarity of mutations in the general population, and the expense of testing. Poland is ideally suited to the study of the genetic
Table 5. Prevalence of BRCA1 gene mutations in unselected breast and ovarian cancer groups and in controls

\begin{tabular}{lcccc}
\hline Parameters & C61G & 4153 delA & 5382insC & Total \\
\hline breast cancer & $15(0.7 \%)$ & $1(0.05 \%)$ & $43(2.1 \%)$ & $59(2.9 \%)$ \\
\hline ovarian cancer & $13(3.6 \%)$ & $8(2.2 \%)$ & $28(7.7 \%)$ & $49(13.5 \%)$ \\
\hline control group & $1(0.05 \%)$ & $1(0.05 \%)$ & $4(0.2 \%)$ & $6(0.3 \%)$ \\
\hline
\end{tabular}

epidemiology of BRCA1 mutations because three common BRCA1 mutations comprise $91 \%$ of all BRCA1 mutations found in the population.

\section{Materials and methods}

To estimate the prevalences and relative risks associated with each of the three founder mutations, we genotyped 2012 unselected cases of breast cancer, 460 unselected cases of ovarian cancer, and 2000 population controls. The control population consisted of 1000 newborn children from throughout Poland and 1000 adults unaffected with cancer from the practices of family physicians in Szczecin. Patients were unselected for age or for family history, and had been diagnosed between 1999 and 2004. Genomic DNA was prepared from peripheral blood leukocytes from patients with breast and ovarian cancer and from adult patients from the control group. In the group of newborn children genomic DNA was prepared from umbilical cord blood leukocytes.

Analysis for three common Polish mutations (4153delA, C61G and 5328insC) was carried out by multiplex PCR. The third mutation (C61G) generates a novel restriction enzyme site in exon 5. This mutation is detected after digesting amplified DNA with Avll.

Research in the breast and ovarian cancer group and in the control group describes the frequency of particular mutations of the BRCA 7 gene. We also compared the ratio of breast to ovarian cancers in an independent set of families with different kinds of BRCA 1 mutation.

\section{Results}

On the basis of frequency of particular BRCAl gene mutations in the unselected groups with breast and ovarian cancer compared with the control group the risk levels of cancer development were specified.

The equivalent odds ratios for ovarian cancer for the 5382insC mutation are 43.6 and for the 4153 delA mutation 50.0. Among carriers of the 4153delA mutation, the odds ratio for breast cancer is 1.0 . 
Among carriers of the 5382ins $\mathrm{C}$ mutation, the odds ratio for breast cancer is 10.9. To confirm the hypothesis that the 4153 delA BRCA1 mutation confers a comparatively low risk of breast cancer, we compared the ratio of breast to ovarian cancers in an independent set of 460 families who had been referred to the hereditary cancer clinic of Szczecin because of two or more cases of breast or ovarian cancer.

These families contained a total of 979 cases of breast cancer and 376 cases of ovarian cancer.

Among the 44 families with the 4153 delA mutation, there were 51 breast and 74 ovarian cancers. Among the 416 families with one of the other two mutations (C61G and 5872insC) there were 928 breast and 302 ovarian cancers. Breast cancer is clearly underrepresented in families with the 4153 delA mutation.

Prevalence of BRCA1 gene mutation and of other alleles presumably linked to predisposition to breast cancer in unselected Polish patients with breast cancer

(Based on publication No. 4: Górski B et al. Breast cancer predisposing alleles in Poland. Breast Cancer Res Treat 2005; 92: 19-24)

Mutant alleles of several genes in the DNA repair pathway have been found to predispose women to breast cancer. From a public health perspective, the importance of a given allele in a population is determined by the frequency of the allele and by the relative risk of breast cancer that it confers.

In Poland founder alleles of the CHEK2 and NBS 1 genes have been associated with an increased risk of breast cancer.

The purpose of the present study is to estimate the prevalence of seven deleterious alleles of three breast cancer predisposing genes (BRCA1, CHEK2, NBS1) in unselected breast cancers.

\section{Materials and methods}

We screened 2012 unselected cases of breast cancer. Each newly diagnosed woman with breast cancer agreed to provide a blood sample for genetic testing and provided information about her family history of breast cancer.

Three control groups were combined. The first group consisted of 2000 newborn children from ten hospitals throughout Poland (Szczecin, Białystok, Gorzów, Katowice, Wrocław, Poznań, Opole, Łódź and Rzeszów). Samples of cord blood from unselected infants were forwarded to the study centre in Szczecin. The second control group was taken from adult patient lists of three family doctors practicing in the Szczecin region. 1000 controls were selected at random from the patient lists of these family doctors. The third control group, with 1000 patients, consisted of adults from Szczecin who submitted blood for paternity testing.

Analysis of BRCA1 mutations. Mutation analysis for three common Polish mutations (4153delA, C61G and 5328ins C) was carried out by a multiplex specific polymerase chain reaction (PCR) assay. To evaluate the accuracy of the multiplex technique the results of 30 samples, representing each of the three mutations and normal DNA samples, were compared. The results of the multiplex PCR assay and the direct DNA sequencing were $100 \%$ concordant.

Analysis of CHEK2 mutations. The IVS2 + 1G > A and $430 T>C$ mutations were identified by RFLP-PCR using Hpy 188III (New England Biolabs). The reverse primer introduced an artificial restriction site for Pstl enzyme.

1100 delC was analyzed using an allele-specific oligonucleotide (ASO-PCR).

Analysis of 657 del5 gene NBS1 mutations. Data collection and analysis was performed using the ASOPCR technique.

In cases in which mutations in BRCA1, CHEK2, and NBS1 genes were detected using the above-mentioned methods, results were verified by sequencing.

\section{Results}

The prevalence, odds ratio and attributable risk estimate associated with each mutant allele (BRCA), CHEK2 and NBS1) are presented in Table 6. The highest odds ratio was associated with missense mutation I C61G and 5382ins $C$. The most common allele in control and patient groups was CHEK2 IVS + IG>A mutation. The presence of any CHEK2 mutation was associated with a $50 \%$ increased risk of cancer (odds ratio $=1.4$ ).

Patients diagnosed under the age of 50 carried a mutation more often. The mean ages of patients were 47.2 years for the BRCA7 -positive cases, 50.7 years for the NBS 1 -positive cases, 54.2 years for the CHEK2positive cases and 56.1 years for the cases with no mutation detected.

Among the CHEK2-positive cases the average age of women with a IVS2 + 1G > A and 1 100delC mutation was 51.0 years, and for women with the lle157Thr mutation it was 55.6 years.

The greatest contrast with age group was for $B R C A 7$; the prevalence of BRCA 1 mutations was $5.5 \%$ among cases diagnosed 50 years and younger and $1.5 \%$ for those diagnosed after age 50 . 


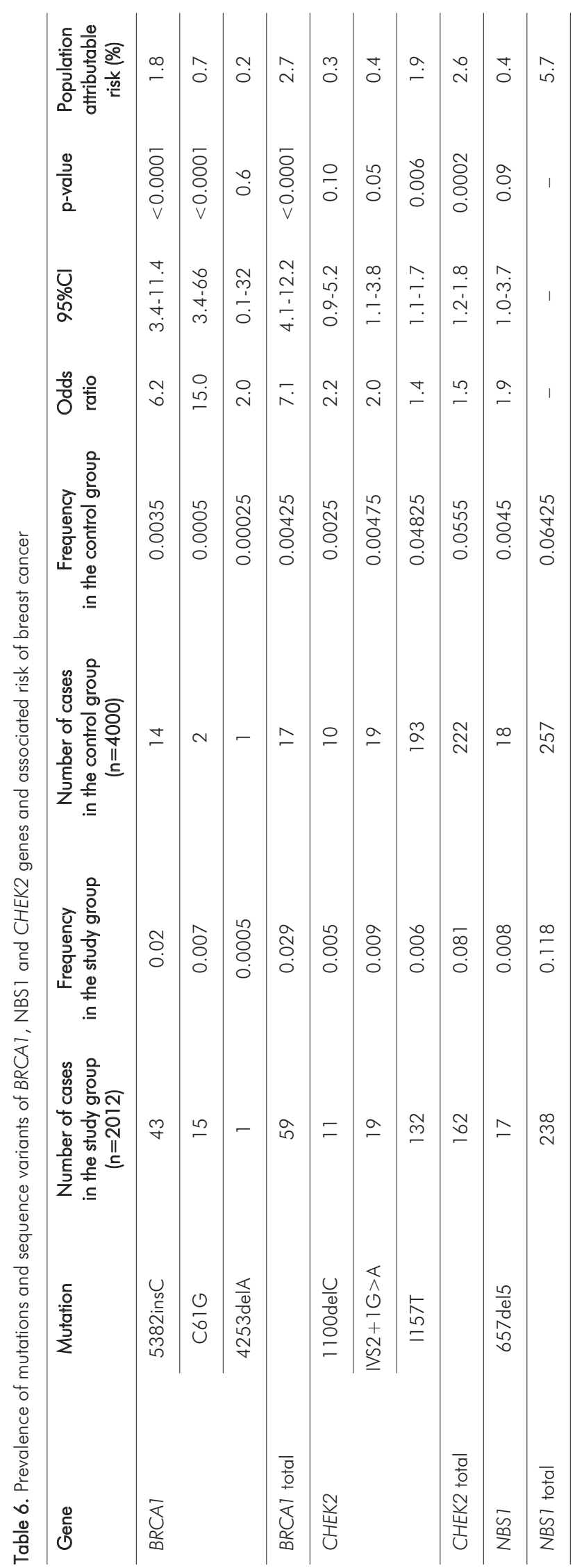

A BRCA1 mutation was much more common in the familial versus non-familial cases $(10.8 \%$ versus $1.3 \%$ ) but this was not true for NBS1 $(0.8 \%$ for both groups) or for CHEK2 (8.8\% for familial versus $7.9 \%$ for non-familial).

Assessment of breast cancer risk in patients with a polymorphism that alters $B R C A 2$ protein structure - detection of increased breast cancer risk in young women with $5972 \mathrm{C} / \mathrm{T}$ polymorphism of the BRCA2 gene

(Based on publication No. 4: Górski B et al. A common missense variant in BRCA2 predisposes to early breast cancer. Breast Cancer Res 2005; 7: 1023-1027)

Mutations in the BRCA2 gene are one of the two major causes of hereditary breast cancer.

A few missense mutations in BRCA2 are believed to have a similarly high penetrance, apart from more common neutral polymorphisms. It is often difficult to classify a particular sequence variant as a mutation or a polymorphism.

There are several approaches to identifying low-penetrance candidate genes for breast cancer. Several deleterious founder alleles have been identified in BRCAl, but to date no founder mutation in BRCA2 has been identified. There are a few common variant alleles in BRCA2 in Poland; one of these (C5972T) changes the amino acid sequence of BRCA2 from methionine to hreonine at codon 915.

The study population included prospectively ascertained cases of invasive breast cancer diagnosed at 50 years of age or less and the control group.

\section{Materials and methods}

We genotyped 3,241 cases of breast cancer diagnosed at less than 51 years of age, unselected for family history, from 18 hospitals throughout Poland. The control group consisted of 1993 newborn children and 798 adult patients unselected for family history.

The C5972T variant was analyzed by restriction fragment length polymorphism PCR-RFLP using the forward primer introducing an artificial restriction site for the Mph 11031 enzyme.

\section{Results}

The C5972T variant was detected in $5.8 \%$ of Polish controls. The overall effect was significant for patients diagnosed at or before age $40(O R=1.4)$ 
Table 7. Prevalence of C5972T polymorphism in the group of unselected breast cancers diagnosed prior to 50 years of age and in the control group

\begin{tabular}{|c|c|c|c|c|c|}
\hline Parameters & Control group & Breast cancers & Odds ratio & $\mathrm{p}$-value & $95 \% \mathrm{Cl}$ \\
\hline \multicolumn{6}{|c|}{ all cancer cases } \\
\hline $\mathrm{CC}$ & 2630 & 3039 & 1.0 & & \\
\hline $\mathrm{CT}$ & 159 & 191 & 1.0 & 0.74 & $0.8-1.3$ \\
\hline TT & 2 & 11 & 4.8 & 0.02 & $1.1-21.4$ \\
\hline $\mathrm{CT}+\mathrm{TT}$ & 161 & 202 & 1.1 & 0.45 & $0.9-1.3$ \\
\hline total & 2791 & 3241 & & & \\
\hline \multicolumn{6}{|c|}{ cancer diagnosed prior to 40 years of age } \\
\hline $\mathrm{CC}$ & 2630 & 598 & 1.0 & & \\
\hline $\mathrm{CT}$ & 159 & 51 & 1.4 & 0.04 & $1.0-2.0$ \\
\hline $\mathrm{TT}$ & 2 & 1 & 2.2 & 0.46 & $0.2-23.7$ \\
\hline $\mathrm{CT}+\mathrm{TT}$ & 161 & 52 & 1.4 & 0.03 & $1.0-1.9$ \\
\hline total & 2791 & 650 & & & \\
\hline \multicolumn{6}{|c|}{ cancer diagnosed past 41 years of age } \\
\hline $\mathrm{CC}$ & 2630 & 2441 & 1.0 & & \\
\hline $\mathrm{CT}$ & 159 & 140 & 0.9 & 0.68 & $0.8-1.2$ \\
\hline $\mathrm{TT}$ & 2 & 10 & 5.4 & 0.02 & $1.2-24.6$ \\
\hline $\mathrm{CT}+\mathrm{TT}$ & 161 & 150 & 1.0 & 0.97 & $0.8-1.3$ \\
\hline total & 2791 & 2591 & & & \\
\hline
\end{tabular}

- Table 7. We reviewed the association between the BRCA2 variant in different histological subgroups and found the effect most pronounced in women who had ductal carcinoma in situ (DCIS) with micro-invasion Table 8.

We found $135972 \mathrm{C} / \mathrm{T}$ homozygotes - 2 in the control group and 11 in the patient group with breast cancer (OR 4.7). Existing reports on the C5972T variant do not record any case of homozygote TT genotypes. It is of interest that the heterozygote state was associated with early onset breast cancer and the homozygote state with later onset cancer.

Family history indicates the occurrence of one or more breast or ovarian cancers among first- and second-degree relatives. For age and tumour size comparisons, $p$-values and confidence intervals refer to the difference of means. Data were missing from the following categories and these cases were excluded from the specific calculations: histology - 909 cases; multi-focality - 1774 cases; bilaterality - 744 cases; oestrogen receptor status - 1746 cases; family history
- 756 cases; family history in group diagnosed $<40$ - 150 cases. Patients who received neo-adjuvant chemotherapy were excluded from all analyses with the exception of family history. 184 patients with BRCA1 mutations were excluded from all analyses. ER+, oestrogen receptor expression positive.

\section{Summary of results}

1. Among 66 families from several regions in Poland with a strong aggregation of breast/ovarian cancer, founder mutations of the BRCAl gene were disclosed in 34 families and of the BRCA2 gene in one family. Altogether, seven different mutations were disclosed. Five mutations were found in at least two families in this group. The most frequent mutation was 5382insC (18 families), followed by C61G (7 families) and 4153delA (4 families).

2. Among 200 families representative for Poland with strong aggregation of breast/ovarian cancer, mutations of the BRCA1 gene were found in 122 families $(61 \%)$ and of the BRCA2 gene in seven 
Table 8. Breast cancer cases associated with $5972 \mathrm{C} / \mathrm{T}$ or TT variants in comparison to the wild $5972 \mathrm{C} / \mathrm{C}$ sequence

\begin{tabular}{|c|c|c|c|c|c|c|c|}
\hline \multirow[t]{2}{*}{ Parameters } & \multicolumn{2}{|c|}{$5972 \mathrm{C} / \mathrm{T}$ or $\mathrm{TT}$} & \multicolumn{2}{|c|}{$5972 \mathrm{C} / \mathrm{C}$} & \multirow[t]{2}{*}{ OR } & \multirow[t]{2}{*}{$\mathrm{p}$-value } & \multirow[t]{2}{*}{$95 \% \mathrm{Cl}$} \\
\hline & $\mathrm{n}$ & $\%$ & $n$ & $\%$ & & & \\
\hline \multicolumn{8}{|c|}{ Histological diagnosis } \\
\hline ductal cancer (\%) & 41 & 36 & 604 & 35 & 1.04 & 0.83 & $0.7-1.5$ \\
\hline lobular cancer (\%) & 22 & 19 & 364 & 21 & 0.90 & 0.70 & $0.5-1.5$ \\
\hline DCIS + microinvasion & 22 & 19 & 121 & 7 & 3.18 & $<0.0001$ & $1.9-5.2$ \\
\hline medullar cancer (\%) & 7 & 6 & 122 & 7 & 0.86 & 0.71 & $0.4-1.9$ \\
\hline tubular or tubulolobular cancer (\%) & 3 & 3 & 104 & 6 & 0.42 & 0.13 & $0.1-1.3$ \\
\hline other & 19 & 17 & 416 & 24 & 0.63 & 0.09 & $0.4-1.0$ \\
\hline multifocal cancer (\%) & 19 & 30 & 211 & 23 & 1.47 & 0.17 & $0.8-2.6$ \\
\hline bilateral cancer (\%) & 7 & 5 & 63 & 3 & 1.71 & 0.18 & $0.7-3.8$ \\
\hline$E R+(\%)$ & 50 & 67 & 583 & 62 & 1.24 & 0.40 & $0.7-2.0$ \\
\hline \multicolumn{8}{|c|}{ Positive family history } \\
\hline all cases & 32 & 21 & 569 & 26 & 0.72 & 0.14 & $0.5-1.2$ \\
\hline cases diagnosed $<40$ years of age & 4 & 10 & 97 & 24 & 0.36 & 0.06 & $0.1-1.1$ \\
\hline & \multicolumn{2}{|c|}{$x$} & \multicolumn{2}{|c|}{$x$} & $\Delta \mathrm{X}$ & $p$-value & $95 \% \mathrm{Cl}$ \\
\hline mean age at diagnosis (years) & \multicolumn{2}{|c|}{43.9} & \multicolumn{2}{|c|}{44.4} & 0.5 & 0.34 & -2 \\
\hline mean tumour size $(\mathrm{cm})$ & \multicolumn{2}{|c|}{2.0} & \multicolumn{2}{|c|}{2.1} & 0.1 & 0.41 & -0.4 \\
\hline
\end{tabular}

families (3.5\%). 119 out of 122 mutations of the BRCA1 gene (97.5\%) were repeatable. Three recurrent mutations of the BRCA1 gene (5382insC, C61G, 4153delA) characteristic for the Polish population were disclosed in 111 families representing $86 \%$ of all pathogenic sequences of this gene.

3. The risk of ovarian cancer in carriers of the three most frequent recurrent mutations of the BRCAl gene in Poland is similar (OR 43.6 for 5382insC and 50 for $4153 \mathrm{de}(\mathrm{A})$. The risk of breast cancer is significantly different for 4153delA (OR 1) and for other mutations (OR 10.9).

4. Among 2012 unselected breast cancers diagnosed in hospitals of nine Polish cities, mutations of the BRCA1 gene (5382insC, C61G, 4153delA) were disclosed in $2.9 \%$ of patients. CHEK2 alternation (1 100delC, IVS2 + 1G>A, I157T) was discovered in $8.1 \%$ and NBS 1 mutation (657del5) in $0.8 \%$ of patients. The changes were more frequent in the study than the control group. However, the risk of breast cancer was significantly higher for only three of them. Two changes, namely 5382ins C and C61G of the BRCA1 gene, revealed a high penetrance $(O R 6.2$ and 15.0, respectively), while 1157 T of the CHEK2 gene was associated with a low risk of breast cancer (OR 1.4).
Mutations of the BRCA1, CHEK2 and NSB 1 genes were significantly more frequent in patients with breast cancer diagnosed prior to 50 years of age. The mean age at diagnosis was 47.2 years for carriers of the BRCA 1 mutation, 50.7 years for NBS 1 and 54.2 for CHEK2. The mean age at diagnosis in the group of patients without any of the mutations described above was 56.1 years.

When breast cancer patients diagnosed before and after 50 years of age were compared, the greatest difference in the frequency of mutations was revealed for the BRCA1 gene (5.5\% vs. $1.5 \%)$.

$B R C A 7$ mutations were significantly more frequent I familial aggregates of the tumour (10.8\%), but were also present in sporadic cases (1.8\%). For the CHEK2 and NBS 1 genes, there was no correlation between frequency and family history of cancer in probands.

5. A higher frequency of heterozygous carriers of $5972 \mathrm{C} / \mathrm{T}$ polymorphism of the BRCA2 gene was demonstrated for breast cancer prior to 50 years of age (OR 1.4). The risk of breast cancer prior to 50 years of age was particularly high in 5972T/T homozygotes (OR 4.7). This polymorphism was associated with breast cancer notable for intraductal growth. 


\section{Conclusions}

1. Efficient molecular diagnostics of genetic predisposition to breast/ovarian cancer in Poland could be based on relatively simple tests disclosing some of the most frequent recurrent mutations of the BRCAl gene.

2. The risk of breast cancer seems to be only slightly higher in carriers of some BRCA1 gene mutations. This finding should be taken into account during work on prevention schemes for carriers of BRCAl mutations.

3. 5382insC and C61G mutations of the BRCA1 gene are linked to high risk of breast cancer. Changes in the CHEK2 and NBS 1 genes appear to be linked to a higher risk of breast cancers, particularly at young age. However, penetrance in this case is low. All patients with breast cancer should be tested for BRCA7 gene mutations because the percentage of mutations is also high in patients older than 50 years of age or without familiar aggregation of breast/ovarian cancer.

4. Polymorphic changes in the BRCA2 gene sequence previously regarded as non-pathogenic may nevertheless predispose, homozygotes in particular, to breast cancer. Apparently, the recessive character of these changes is responsible for the negative family history in most cases. The use of DNA tests is the only way to disclose increased risk of breast cancer in carriers of the $5972 \mathrm{~T} / \mathrm{T}$ mutation.

\section{References}

1. Friedman LS, Ostermeyer EA, Szabo Cl, Dowd P, Lynch ED, Rowell SE and King MC. Confirmation of BRCA1 by analysis of germline mutations linked to breast and ovarian cancer in ten families. Nat Genet 1994; 8: 399-404.

2. Tonin P, Weber B, Offit K, Couch F, Rebbeck TR, Neuhausen S, Godwin AK, Daly M, Wagner-Costalos J, Berman D, Grana G, Fox E, Kane MF, Kolodner RD, Krainer M, Haber DA, Struewing JP, Warner E, Rosen B, Lerman C, Peshkin B, Norton L, Serova $O$, Foulkes WD, Garber JE, et al. Frequency of recurrent BRCA1 and BRCA2 mutations in Ashkenazi Jewish breast cancer families. Nat Med 1996; 2: $1179-1183$

3. Lee JS, Collins KM, Brown AL, Lee CH and Chung JH. hCds 1 mediated phosphorylation of BRCA1 regulates the DNA damage response. Nature 2000; 404: 201-204

4. Davies AA, Masson JY, Mcllwraith MJ, Stasiak AZ, Stasiak A, Venkitaraman AR and West SC. Role of BRCA2 in control of the RAD51 recombination and DNA repair protein. Mol Cell 2001 7: 273-282.

5. Spurdle AB, Hopper JL, Chen X, Dite GS, Cui J, McCredie MR, Giles GG, Ellis-Steinborner S, Venter DJ, Newman B, Southey MC and Chenevix-Trench $\mathrm{G}$. The BRCA2 $372 \mathrm{HH}$ genotype is associated with risk of breast cancer in Australian women under age 60 years. Cancer Epidemiol Biomarkers Prev 2002; 11: 413-416.

6. Goode EL, Ulrich CM and Potter JD. Polymorphisms in DNA repair genes and associations with cancer risk. Cancer Epidemiol Biomarkers Prev 2002; 11: 1513-1530

7. Lahiri DK and Schnabel B. DNA isolation by rapid method from human blood samples: effects $\mathrm{MgCl}_{2}$, EDTA, storage time, and temperature on DNA yield and quality. Biochem Genet 1993; $31: 321-328$
8. van Der Looij M, Wysocka B, Brozek I, Jassem J, Limon J and Olah E. Founder BRCA1 mutations and two novel germline BRCA2 mutations in breast and/or ovarian cancer families from North-Eastern Poland. Hum Mutat 2000; 15: 480-481.

9. Grzybowska E, Zientek H, Jasinska A, Rusin M, Kozlowski P, Sobczak K, Sikorska A, Kwiatkowska E, Gorniak L, Kalinowska E, Utracka-Hutka B, Wloch J, Chmielik E and Krzyzosiak WJ. High frequency of recurrent mutations in BRCA1 and BRCA2 genes in Polish families with breast and ovarian cancer. Hum Mutat 2000; 16: 482-490.

10. Jasinska A and Krzyzosiak WJ. Prevalence of BRCA1 founder mutations in western Poland. Hum Mutat 2001; 17: 75.

11. Kwiatkowska E, Brozek I, lzycka-Swieszewska E, Limon J and Mackiewicz A. Novel BRCA2 mutation in a Polish family with hamartoma and two male breast cancers. J Med Genet 2002; 39: E35.

12. Paszko Z, Skasko E, Wisniewska A, Konopna B, Kluska A, Jasielska $A$, et al. Changes in BRCAl gene in patients with familiar breast cancer in Warsaw region of Poland. Nowotwory J Oncol 2002; 52: 97-103.

13. De los Rios P, Jack E, Lynch H, Lubinski J and Narod SA. Founder mutations of BRCA1 and BRCA2 in North American families of Polish origin that are affected with breast cancer. Am J Hum Genet 2001 ; 68: 546.

14. Janiszewska $H$, Haus $O$, Lauda-Swieciak A, Pasinska M, Laskowski R, Szymanski W, Gorski B and Lubinski J. Frequency of three BRCAl gene founder mutations in breast/ovarian cancer families from the Pomerania-Kujawy region of Poland. Clin Genet 2003; 64: 502-508.

15. Perkowska M, BroZek I, Wysocka B, Haraldsson K, Sandberg T, Johansson U, Sellberg G, Borg A and Limon J. BRCA1 and BRCA2 mutation analysis in breast-ovarian cancer families from northeastern Poland. Hum Mutat 2003; 21 : 553-554.

16. Meijers-Heijboer $H$, van den Ouweland A, Klijn J, Wasielewski M, de Snoo A, Oldenburg R, Hollestelle A, Houben M, Crepin $E$, van Veghel-Plandsoen $M$, Elstrodt F, van Duijn C, Bartels $C$, Meijers C, Schutte M, McGuffog L, Thompson D, Easton D, Sodha N, Seal S, Barfoot R, Mangion J, Chang-Claude J, Eccles D, Eeles R, Evans DG, Houlston R, Murday V, Narod S, Peretz T, Peto J, Phelan C, Zhang HX, Szabo C, Devilee P, Goldgar D, Futreal PA, Nathanson KL, Weber B, Rahman N, Stratton MR and CHEK2-Breast Cancer Consortium. Low-penetrance susceptibility to breast cancer due to $\mathrm{CHEK} 2\left(^{*}\right) 1100 \mathrm{delC}$ in noncarriers of BRCA1 or BRCA2 mutations. Nat Genet 2002; 31 : 55-59.

17. Cybulski C, Huzarski T, Gorski B, Masoic B, Mierzejewski M, Debniak T, Gliniewicz B, Matyjasik J, Zlowocka E, Kurzawski G, Sikorski A, Posmyk M, Szwiec M, Czajka R, Narod SA and Lubinski J. A novel founder CHEK2 mutation is associated with increased prostate cancer risk. Cancer Res 2004; 64: 2677-2679.

18. Gorski B, Debniak T, Masojc B, Mierzejewski M, Medrek K, Cybulski C, Jakubowska A, Kurzawski G, Chosia M, Scott R and Lubinski J. Germline 657del5 mutation in the NBS 1 gene in breast cancer patients. Int J Cancer 2003; 106: 379-381.

19. Masojć B, Mierzejewski M and Górski B. Constitutional mutations in NBS1 gene in patients with sporadic and hereditary cancer of mammary gland. International Congress for Students and Young Physicans. Warsaw, April 2001, Poland, Book of Abstracts 2001.

20. Steffen J, Varon R, Thomas M, Stumm M, Maurer M, Nowakowska D, et al. The frequency of heterozygous germline mutation 657 del5 in cancer patients from Poland. International Workshop on Nijmegen Breakage Syndrome. Prague, April 2002, Czech Republic. Cs. Lek. Csk. 141, 202 C. Suppl. 8, Book of Abstracts 